\title{
Food security in the context of climate change and bioenergy production in Tanzania: methods, tools and applications
}

\author{
Stefan Sieber ${ }^{1} \cdot$ Karen Tscherning $^{2} \cdot$ Frieder Graef $^{1} \cdot$ Götz Uckert $^{1}$ • \\ Sergio Gomez y Paloma $^{3}$
}

Received: 4 June 2015/Accepted: 14 June 2015/Published online: 21 July 2015

(c) Springer-Verlag Berlin Heidelberg 2015

\begin{abstract}
A dramatic population growth is projected for the least developed countries of the world (United Nations 2013), which will also suffer disproportionally from ongoing and predicted climate disruptions (IPCC 2013). More frequently occurring extreme weather events have led to yield losses and decreasing cattle populations-aggravating an already precarious situation and leading to critical food shortages. Food security is a function of food availability, food accessibility, food stability and food utilisation (FAO 2002; Ziervogel and Ericksen 2010). Climate change and population growth are seen as key drivers of food insecurity severely affecting farming systems (Müller et al. 2011; Haberl et al. 2011, Strengers et al. 2010), as well as the global energy demand and therefore induced biofuel production (Von Braun 2007a), changing trade patterns through liberalisation and globalisation (Von Braun 2007b; Lotze-Campen et al. 2010), and the state of health of the population (10-20\% AIDS rate in East Africa). Causeeffect chains, in which food security is involved (droughtsdiseases-health-human capital), are also drivers over large regions (Ziervogel and Ericksen 2010). Most of these
\end{abstract}

Disclaimer The views expressed are purely those of the authors and may not in any circumstances be regarded as stating an official position of the European Commission.

Götz Uckert

goetz.uckert@zalf.de

1 Leibniz Centre for Agricultural Landscape Research (ZALF), Müncheberg, Germany

2 Deutsche Gesellschaft für Internationale Zusammenarbeit (GIZ), Dag-Hammarskjöld-Weg 1-5, Eschborn, Germany

3 Institute for Prospective Technological Studies (IPTS), European Commission, Joint Research Centre (JRC), Seville, Spain drivers do not only lead to a productivity decline, but also often result in a degraded natural resource base and declining soil fertility (Graef et al. 2000). Rapidly changing framework conditions (Müller 2011) require a thorough understanding of integrated food systems and targeted incorporation of region-specific innovations.

However, creating a sustainable road map for the future is a huge challenge for a variety of reasons. Mainly rainfed, subsistence-oriented smallholder farming systems are not only extremely vulnerable to a changing and unpredictable climate, but often also lack access to external inputs, institutional support and adaptive capacity. Moreover, food insecurity is often regarded as insufficient food availability which is only part of the picture. Instead of solely focussing on boosting crop yields, the highly complex state of vulnerability needs to be addressed encompassing economic and sociopolitical factors (Misselhorn 2004; Pretty et al. 2006). Also, increased bioenergy production has fuelled land use conflicts and lead to largescale deforestation due to the growing international demand for biofuels. Biomass is still the primary source of energy in developing countries-important for income, energy supply, poverty reduction and self-sufficiency of rural communities (Harvey and Pilgrim 2011; Mitchell 2011; Tilman et al. 2009). Effective climate change adaptation and food security intervention strategies need to pursue a holistic approach and an array of objectives: social and economic viability, soil health, minimum use of scarce water and fossil energy, affordable and low external inputs, improvement in infrastructure and market access, as well as conservation of natural resources and biodiversity. To achieve positive impacts and sustainable solutions, international research projects increasingly focus on integrated in-depth analysis of the food system itself and its core elements: (a) natural and human resources, (b) the use of 
production inputs, (c) the safety and quality of food produced, (d) the consumption patterns and (e) functioning of local and global markets (Foley et al. 2011). This analysis needs to cover specific cultural, political, social, ecological and economic aspects. The involvement of local stakeholders and consideration of site-specific conditions is of paramount importance for sustained success (Below et al. 2012; König et al. 2012; Reed et al. 2009).

In this special issue, we present results from research projects in Tanzania. The East African country has experienced very high population growth: a rate of $2.7 \%$ since 2002 (National Bureau of Statistics 2013). Despite overall positive developments in the past years, a large amount of the population faces extreme poverty. About $75 \%$ live in rural households, which constitute $80 \%$ of the country's poor (World Bank 2013). Smallholder farmers dominate the country's agriculture, which is the main source of employment and livelihood for about $77.5 \%$ of the population. But despite its critical role for the population, the agricultural sector does not prosper and has not performed satisfactorily (Ministry of Agriculture, Food Security and Cooperatives 2013). Tanzania still is a very low-income country ranking 152 out of 186 countries in the 2012 UNDP Human Development Index and among those African countries with the highest levels of malnutrition (Pauw and Thurlow 2011). Forty-two per cent of children aged under 5 years are stunted (WFP 2013). Climate change is one driver of food insecurity and poses a serious risk to Tanzania. Modelled climate change scenarios consistently predict increases in country's averaged mean temperatures of 1.3 and $2.2{ }^{\circ} \mathrm{C}$ projected by 2050 and 2100 (Agrawala et al. 2003). However, projected trends in precipitation and its impact on crop yields seem uncertain (Kilembe et al. 2012). Furthermore, food supply systems of Tanzania are increasingly connected to other biomass production systems such as feed, biofuel and construction wood (Mnenwa and Maliti 2010). These production systems are based on complex and multiple interactions and interrelations among a wide range of different biotic and abiotic resources as well as socio-economic and cultural parameters (USAID 2008). They provide food and energy, also generating income. However, if the food and energy value chains are not developed properly, the effects may include increased food prices and reduced supply (Foley et al. 2011), displacement of vulnerable people from productive land and various negative environmental impacts (Thornton et al. 2006).

In this special issue, we focus on the tools, methods and approaches that will be needed to meet the challenge of adaptation to climate change supporting decision-making for a sustainable development. We also apply integrated analyses to improve the food situation at the local-level and upscale successful upgrading strategies. Against this background, this special issue presents results of four research projects in Tanzania, which were mainly aimed at

- reducing the vulnerability of rural households to climate change and enhancing livelihoods,

- exploring the conflict between bioenergy, food production and forest conservation,

- creating tools to identify and implement appropriate adaptation and upgrading strategies,

- assessing the regional impacts of climate change on agriculture and environment,

- and, ultimately, improving the adaptive capacity of smallholder communities.

In order to raise acceptance of sustainable adaptation measures in response to climatic changes, it is essential to assess farmers' knowledge on the risks that they are facing and the multi-dimensional factors influencing that perception. Below et al. (2014) analysed the agricultural adaptation context in two Tanzanian villages with different agro-ecological conditions employing the newly developed agricultural adaptation and perception model (AAP). Empirical data were collected and coded along five dimensions: non-climatic determinants of vulnerability (1), general trends in livelihood strategies (2), perception of climatic trends (3), climate impacts in agriculture (4) and potentials and obstacles for adaptation (5). Farmers identify poor and unreliable rainfall as significant agricultural stressor along with poor extension services, lack of fertile land and inputs, problems of pests and diseases and poor access to markets. Although the participants of the focus group discussions agree that climatic conditions have become more challenging over the last few years, the results show that adaptation levels as well as perceptions and narratives about climatic and yield dynamics differ considerably among the two farming communities. Perceptions in rural communities are heterogeneous and similar changes in external climatic stressors can lead to very different local impacts. Consequently, the authors stress that for improving food security in the face of climate change, farmers' perceptions and the multi-functionality of agricultural systems need to be explicitly recognised and detailed vulnerability assessments are of paramount importance.

Energy is a vital component in the quality of life of rural communities. In developing regions, access to adequate biomass is crucial, especially as primary source of energy for cooking. However, increasing pressure on natural resources related to population growth leads to land use changes with a potentially devastating impact on the environment and climate. Hoffmann et al. (2014a) analysed the firewood and charcoal consumption patterns of villagers in Laela, Western Tanzania, and examined how introducing a specific firewood-reliant efficient stove technology would affect energy consumption for the years 2015 and 2030. The results show that poorer households 
are highly dependent on firewood, while charcoal consumption is largely limited to higher-income classes. Furthermore, the results provide evidence that the use of efficient stoves can substantially reduce energy consumption in the mid-to-long term. In light of these findings, the authors suggest income-group-specific distribution of efficient stoves in order to optimise energy savings.

In a second paper of Hoffmann et al. (2014b), the research team focused on the impacts of biofuel production for rural electrification on development and food security in the village of Laela in Western Tanzania. Based on a village survey, focus group discussions and expert interviews, the potential food security effects on four different economic types of farmer groups were calculated. The objective of the analysis was to evaluate the potential use of locally produced sunflower and groundnut oils as substitutes for fossil fuels for the production of electricity. The results show that the replacement of food crops with crops producing biofuel will most likely impact local food security negatively and does not contribute to human wellbeing in the selected village. The authors conclude that energy self-sufficiency of African income-diverse rural communities without compromising the food supply is a desired state but remains a big challenge.

Faße and Grote (2013) examined the role of Jatropha curcas in the livelihood of smallholder farmers in Tanzania. The oil of Jatropha can be converted into biodiesel making it a suitable bioenergy plant, but it is also cultivated as a supporting plant for spice production. To explore its role in rural households' livelihood strategies, a factor, cluster and a regression analyses were conducted using household data from a village in eastern Tanzania. Three different livelihood strategies were identified: (1)"subsistence farm households combined with unskilled wage employment", (2) "farm households highly specialised in cash crop production" and (3) "farm households specialised in cash crop production combined with skilled off-farm employment". The results show that Jatropha is used as a host plant for black pepper and vanilla for income generation, with households from cluster 3 having the highest income from cultivation of Jatropha/spices. However, for poorer households, the share of income from Jatropha/ spices has been quite significant with up to $30 \%$. Also, with respect to environmental outcomes, it was indicated that farm households from the third cluster are able to manage their farms more sustainably compared with clusters 1 and 2 (e.g. measures against soil erosion, voluntary forest protection). Human and financial capital, transaction costs and institutional factors are identified as explanations for differences in the livelihood portfolios. The results underline the importance of agroforestry for small-scale farmers and differentiating households according to their livelihood strategies for targeted interventions.
In their paper, Winter et al. (2014) address the challenges associated with rapid population growth and correspondingly increasing energy needs in sub-Saharan Africa, leading to the depletion and degradation of forest ecosystems. In particular in Eastern Africa, forest products sustain the livelihoods of the rural population by generating income, food security and energy. A computable village model was developed to analyse the impact of alternative resource management strategies on local income distribution and resource use over the long term, exploring the example of the Kakamega forest. The model results confirm the importance of forest goods and services as source of income for poor rural people. They further indicate that the feasibility of sustainable forest management depends on the establishment of alternative energy systems in rural communities, such as small-scale Jatropha production.

The global demand for palm oil is spiralling and associated with further deforestation leading to loss of biodiversity, exacerbating climate change and other negative externalities. Intensification strategies are required that avoid land use changes. Uckert et al. (2015) explored the situation in the Western Tanzanian province of Kigoma where palm oil production is dominated by small-scale subsistence farming systems that are characterised by low productivity and low yields. The palm oil trees (POTs) are mainly used for producing cooking oil and as source of firewood. By conducting stakeholder interviews, focus group discussions and a household survey, they analysed production and processing methods evaluating existing best practices and identifying factors which may have a positive impact on production levels. The results indicate large differences between output levels resulting from processing technologies and/or agricultural management practices (e.g. using hybrid varieties, sub-optimal planting densities and low weeding or organic fertilising inputs). Consequently, the authors call for action to raise farmers' willingness to adopt new forest-farming systems. They suggest that the productivity of small-scale palm oil production systems could be improved by a variety of measures like mixed cropping, unproductive POT replacement strategy and general intensification of plant maintenance. Also, a shift from subsistence to sustainable and market-orientated production may generate income opportunities for farmers. This, however, requires development along the entire value chain to ensure that obstacles concerning transport, processing and marketing or quality management are minimised.

Mutabazi et al. (2015a) systematically analysed the determinants of poverty and vulnerability of farmers in rural semi-arid areas with varying agro-ecological potentials in the context of climate change. The data were collected through a cross-sectional survey covering 240 households in six villages of Morogoro region, Tanzania, as well as descriptive and econometric approaches. Results indicate that income poverty was generally prevalent in the 
study area, but relatively higher in the area with less favourable agro-climate. Correspondingly, over three quarters of the sample households were vulnerable. Identified drivers include ageing and large size of the household. In contrast, farming experience and increased farm size reduced the probability of future vulnerability. In response to these findings, the authors conclude that (1) climate change will further adversely affect the poor and vulnerable already living under unfavourable climatic conditions, (2) old-age related poverty and vulnerability must be addressed through dedicated policies and programs (e.g. pension schemes), (3) increasing the farm size would enhance smallholder farm income (within the resource limits of the household), and (4) improving rural income through targeted activities will enhance the living standard and build livelihood resilience.

In a second paper of Mutabazi et al. (2015b) the group of authors identify a set of resilience-building adaptive strategies such as intensification, diversification, alteration, migration among farmers in Morogoro, Tanzania. It crafts a composite index of these strategies using a principal component analysisbased weighting scheme. The analysis reveals the latent structure and internal correlations of actions intended to build resilience of the farming systems. The results highlight the need of enhancing livelihood resources to enhance the ability to undertake adaptive strategies that denotes the ability to withstand stresses and shocks from climatic changes. The authors require that actions to improve human capital, social capital, financial capital and natural capital are needed in order to impart resilience to the farming systems against the changing climate.

A rapidly growing population puts pressure on water resources. Natkhin et al. (2013) investigated the reasons for the changes in the run-off characteristic of the Ngerengere River in Tanzania during recent years. Using a combination of statistical analysis and modelling, they identified changes in land use and climate boundaries as causes, although they do not have a uniform effect on discharge in the catchment. Changing land use affects surface run-off and increases floods in the mountainous areas. Changes in climate boundaries increase the duration of low flow and no flow in the catchment. Interestingly, changes in climate conditions and land use had antipodal effects on parts of the discharge regime and partially compensate for each other.

Sieber et al. (2015) address the need and challenge of spreading existing climate-resilient sustainable agricultural (CRSA) practices by replicating successful ones in other locations (Scaling-up). In their paper, they evaluate different tools that can assist the scaling-up of CRSA practices and present an integrative assessment tool, ScalA (Scaling up Assessment Tool). Case studies from Morogoro, Tanzania showcase the tool's capacity in assessing the potential (in scaling-up) of an array of CRSA practices in one region and one specific CRSA practice in various regions. The analysis starts with an assessment of the project's ecologic/economic/social sustainability as a precondition for further scaling-up (step 1), which is followed by a an assessment of a project's effects on adaptive capacity (step 2 ) and resilience to climate change (step 3), employment of adaptation strategies (step 4) and greenhouse gas mitigation effects (step 5). The next step (6) ensures that only feasible project approaches meeting basis criteria for implementation are considered for scaling-up. The tool then reviews the importance of financial, human resource, institutional and infrastructural preconditions for successful implementation and scaling-up of the project approach (step 7). The last step (8) makes sure that the project approach does not deviate from a scaling-up situation. The authors conclude that the step-by-step methodology of the ScalA tool is fairly easy to apply and interpret, and although there is room for improvement and further development, it may help to successfully facilitate decision-making processes among policy makers, as well as practitioners at community level concerned with the planning and monitoring of implementation processes for CRSA practices.

The papers here focus on the need for participatory, transdisciplinary and integrated research to deal effectively with the challenges associated with adaptation to climate change and stabilisation of food security. To cope with the changing conditions in Tanzania, profound knowledge of the local and regional environmental and socio-economic systems is required for decision-making, for instance, on long-term conservation of natural resources (König et al. 2012), and on adequate technologies and strategies to ensure food security (Graef and Haigis 2001; Waha et al. 2013; Ziervogel and Ericksen 2010). Trade-off food system analysis of the limited resources and human factors testing site-specific approaches are therefore one requirement for mid- and long-term improvement in the livelihoods of food-insecure Tanzanians. Here a vital element is the participatory involvement of existing local knowledge on good practices in a people-centred approach with both local population and institutions (König et al. 2012; Reidsma et al. 2011; Ziervogel and Ericksen 2010). At the same time, it needs to be combined with the major national Tanzanian political programmes on food security-the Agricultural Sector Development Strategy (ASDS), the Agricultural Sector Development Programme (ASDP), the overall National Strategy for Growth and Reduction of Poverty (NSGRP) — and with international African political and/or development programmes such as the New Partnership for Africa's Development (NEPAD). Hence, new approaches and solutions in conducting research are required along with innovative collaboration with administration, institutions, stakeholders and other carriers of knowledge (Hounkonnou et al. 2012). 
Acknowledgments The authors would like to thank Anke Wolff for her contributions to this editorial as well as Fatmir Guri, Andriy Kharchenko, Laura Riesgo and Pedro Andrés Garzon Delvaux for their support.

\section{References}

Agrawala S, Moehner A, Hemp A, van Aalst M, Hitz S, Smith J, Meena H, Mwakifwamba SM, Hyera T, Mwaipopo OU (2003) Development and climate change in Tanzania: focus on Mount Kilimanjaro. OECD, Paris

Below T, Mutabazi KD, Kirschke D, Franke C, Sieber S, Siebert R, Tscherning K (2012) Can farmers' adaptation to climate change be explained by socio-economic household-level variables? Glob Environ Chang 22(1):223-235. doi:10.1016/j.gloenvcha.2011. 11.012

Below T et al (2014) Farmers' knowledge and perception of climatic risks and options for climate change adaptation: a case study from two Tanzanian villages. Reg Environ Change. doi:10.1007/ s10113-014-0620-1

Faße A, Grote U (2013) The role of Jatropha curcas cultivation in livelihood strategies of small-scale households in rural Tanzania. Reg Environ Change. doi:10.1007/s10113-013-0494-7

FAO (2002) Reducing poverty and hunger, the critical role of financing for food, agriculture and rural development. Paper Prepared for the International Conference on Financing for Development, Monterrey, Mexico, FAO Rome, 18-22 March 2002

Foley JA, Ramankutty N, Brauman KA, Cassidy ES, Gerber JS, Johnston M, Mueller ND, O'Connell C, Ray DK, West PC, Balzer C, Bennett EM, Carpenter SR, Hill J, Monfreda C, Polasky S, Rockström J, Sheehan J, Siebert S, Tilman D, Zaks DP (2011) Solutions for a cultivated planet. Nature 478:337-342. doi:10.1038/nature10452

Graef F, Haigis J (2001) Spatial and temporal rainfall variability in the Sahel and effects on farmers' management strategies. J Arid Environ 48(2):221-231. doi:10.1006/jare.2000.0747

Graef F, Lawrence P, von Oppen M (eds) (2000) Adapted farming in West Africa: issues, potentials and perspectives-Final Report (1986-1999) of the Special Research Programme 308 "Adapted Farming in West Africa”. Verlag Ulrich Grauer, Stuttgart

Haberl H, Erb H, Krausmann KH, Bondeau F, Lauk A, Müller C, Plutzar C, Steinberger JK (2011) Global bioenergy potentials from agricultural land in 2050: sensitivity to climate change, diets and yields. Biomass Bioenerg 35(12):4753-4769. doi:10. 1016/j.biombioe.2011.04.035

Harvey M, Pilgrim S (2011) The new competition for land: food, energy, and climate change. Food Policy 36:S40-S51. doi:10. 1016/j.foodpol.2010.11.009

Hoffmann $\mathrm{H}$ et al (2014a) Local biofuel production for rural electrification potentially promotes development but threatens food security in Laela, Western Tanzania. Reg Environ Change. doi:10.1007/s10113-014-0596-x

Hoffmann $\mathrm{H}$ et al (2014b) Traditional biomass energy consumption and the potential introduction of firewood efficient stoves: insights from western Tanzania. Reg Environ Change. doi:10. 1007/s10113-014-0738-1

Hounkonnou D, Kossou D, Kuyper TW, Leeuwis C, Nederlof ES, Röling N, Sakyi-Dawson O, Traoré M, van Huis A (2012) An innovation systems approach to institutional change: smallholder development in West Africa. Agric Syst 108:7483. doi:10.1016/ j.agsy.2012.01.007

IPCC (2013) Summary for policymakers. In: Stocker TF, Qin D, Plattner G-K, Tignor M, Allen SK, Boschung J, Nauels A, Xia
Y, Bex V, Midgley PM (eds) Climate change 2013: the physical science basis. Contribution of working group I to the fifth assessment report of the intergovernmental panel on climate change, Cambridge University Press, Cambridge, New York, pp 1-30

Kilembe C, Thomas TS, Waithaka M, Kyotalimye M, Tumbo S (2012) East African agriculture and climate change: a comprehensive analysis-Tanzania. IFPRI, Washington

König HJ, Sghaier M, Schuler J, Abdeladhim M, Helming K, Tonneau JP, Ounalli N, Imbernon J, Morris J, Wiggering H (2012) Participatory impact assessment of soil and water conservation scenarios in Oum Zessar Watershed Tunisia. Environ Environ Manage 50(1):153-165. doi:10.1007/s00267012-9865-y

Lotze-Campen H, Popp A, Beringer T, Müller C, Bondeau A, Rost S, Lucht W (2010) Scenarios of global bioenergy production: the trade-offs between agricultural expansion, intensification and trade. Ecol Model 221:2188-2196. doi:10.1016/j.ecolmodel. 2009.10.002

Ministry of agriculture, food security and cooperatives-Tanzania (2013) Overview. http://www.agriculture.go.tz/agriculturalstatis tics/angriculturalstatistics.htm. Accessed 20 Nov 2013

Misselhorn A (2004) What drives food insecurity in southern Africa? A meta-analysis of household economy studies. Glob Environ Chang 15:33-43. doi:10.1016/j.gloenvcha.2004.11.003

Mitchell D (2011) Biofuels in Africa. Opportunities, prospects and challenges. The World Bank, Washington

Mnenwa R, Maliti E (2010) A comparative analysis of poverty incidence in framing systems of Tanzania. Special paper 10/4. REPOA. $\mathrm{p} 27$

Müller C (2011) Harvesting from uncertainties. Natl Clim Chang 1(5):253-254. doi:10.1038/nclimate1179

Müller C, Cramer W, Hare WL, Lotze-Campen H (2011) Climate change risks for African agriculture. Proc Natl Acad Sci USA (PNAS) 108(11):4313-4315. doi:10.1073/pnas.1015078108

Mutabazi KD et al (2015a) Assessing the determinants of poverty and vulnerability of smallholder farmers in a changing climate: the case of Morogoro region, Tanzania. Reg Environ Change. doi:10.1007/s10113-015-0772-7

Mutabazi KD et al (2015b) Influence of livelihood resources on adaptive strategies to enhance climatic resilience of farm households in Morogoro, Tanzania: an indicator-based analysis. Reg Environ Change. doi:10.1007/s10113-015-0800-7

National Bureau of Statistics/Ministry of Finance-Tanzania (2013) 2012 Population and Housing Census. http://www.ocgs.go.tz. Accessed 2 Feb 2014

Natkhin M et al (2013) The effects of climate and changing land use on the discharge regime of a small catchment in Tanzania. Reg Environ Change. doi:10.1007/s10113-013-0462-2

Pauw K, Thurlow J (2011) Agricultural growth, poverty, and nutrition in Tanzania. Food Policy 36(6):795-804

Pretty J, Noble AD, Bossio D, Dixon J, Hine RE, Penning De Vries FW, Morison JI (2006) Resource-conserving agriculture increases yields in developing countries. Environ Sci Technol 40(4): 1114-1119

Reed M, Graves A, Dandy N, Posthumus H, Hubacek K, Morris J, Prell C, Quinn CH, Stringer LC (2009) Who's in and why? A typology of stakeholder analysis methods for natural resource management. J Environ Manage 90(5):1933-1949. doi:10.1016/ j.jenvman.2009.01.001

Reidsma P, König HJ, Feng S, Bezlepkina I, Nesheime I, Bonin M, Sghaier M, Purushothaman S, Sieber S, van Ittersum MK, Brouwer F (2011) Methods and tools for integrated assessment of land use policies on sustainable development in developing countries. Land Use Policy 28(3):604-617. doi:10.1016/j.land usepol.2010.11.009 
Sieber S et al (2015) Integrated assessment of sustainable agricultural practices to enhance climate resilience in Morogoro, Tanzania. Reg Environ Change. doi:10.1007/s10113-015-0810-5

Strengers BJ, Müller C, Schaeffer M, Haarsma RJ, Severijns C, Gerten D, Schaphoff S, van den Houdt R, Oostenrijk R (2010) Assessing 20th century climatevegetation feedbacks of land-use change and natural vegetation dynamics in a fully coupled vegetation-climate model. Int J Climatol 30(13):2055-2065. doi: $10.1002 /$ joc. 2132

Thornton PK, Jones PG, Owiyo T, Kruska RL, Herrero M, Kristjanson P, Notenbaert A, Bekele N, Omolo A, with contributions from Orindi V, Otiende B, Ochieng A, Bhadwal S, Anantram K, Nair S, Kumar V and Kulkar U (2006) Mapping climate vulnerability and poverty in Africa. Report to the Department for International Development, ILRI, PO Box 30709, Nairobi 00100, Kenya. p 171

Tilman D, Socolowb R, Foley JA, Hill J, Larson E, Lynd L, Pacala S, Reilly J, Searchinger T, Somerville C, Williams R (2009) Beneficial biofuels-the food, energy, and environment trilemma. Science 325:270-271. doi:10.1126/science. 1177970

Uckert $\mathrm{G}$ et al (2015) Increase without spatial extension: productivity in small-scale palm oil production in Africa-the case of Kigoma, Tanzania. Reg Environ Change. doi:10.1007/s10113015-0798-X

United Nations, Department of Economic and Social Affairs, Population Division (2013) World population prospects: the 2012 revision, key findings and advance tables. Working Paper No. ESA/P/WP.227
USAID (2008) Preliminary rural livelihood zoning: Tanzania; A special report by the famine early warning system network. http://www.fews.net/sites/default/files/documents/reports/tz_ zonedescriptions_en.pdf. Accessed 7 July 2014

Von Braun J (2007a) Eliminating hunger and reducing poverty focus on the world's poorest and hungry people. Essays. IFPRI, Washington

Von Braun J (2007b) The world food situation, new driving forces and required actions. IFPRI, Washington. doi:10.2499/ 0896295303

Waha K, Müller C, Bondeau A, Dietrich JP, Kurukulasuriya P, Heinke J, Lotze-Campen H (2013) Adaptation to climate change through the choice of cropping system and sowing date in subSaharan Africa. Glob Environ Change 23:130-143. doi:10.1016/ j.gloenvcha.2012.11.001

Winter E et al (2014) Food security, energy equity, and the global commons: a computable village model applied to sub-Saharan Africa. Reg Environ Change. doi:10.1007/s10113-014-0674-0

World Bank (2013) Tanzania Overview. http://www.worldbank.org/ en/country/tanzania/overview. Accessed 3 Dec 2013

World Food Programme (WFP) (2013) Overview-United Republic of Tanzania. http://www.wfp.org/countries/tanzania-unitedrepublic-of/overview. Accessed 10 Dec 2013

Ziervogel G, Ericksen PJ (2010) Adapting to climate change to sustain food security. WIREs Clim Change 1:525-540. doi:10. 1002/wcc.56 